\title{
Optimum Plant Density of Okra and Intercropping Effects on Yields of Egusi melon-Okra Mixture, at Makurdi, Nigeria
}

\author{
Michael Ojore ljoyah $^{1^{*}}$ Felix Terna Fanen $^{2}$, Francis Doo Aindigh ${ }^{2}$ \\ ${ }^{1}$ Department of Crop Production, University of Agriculture, P.M.B. 2373, Makurdi, Nigeria \\ ${ }^{2}$ Department of Crop Production Technology, Akperan Orshi College of Agriculture, Yandev, \\ Nigeria \\ *E-mail address: mikejoy2005@yahoo.com
}

Keywords: intercropping; plant density; egusi melon; okra; Nigeria

\begin{abstract}
A field experiment was conducted from August to November, during the 2012 and 2013 cropping seasons at the Research Farm, University of Agriculture, Makurdi, Nigeria, to identify the optimum plant density of okra and intercropping effects on yields of egusi melon-okra mixture and to assess the yield advantages of the intercropping system. The experiment was a $3 \times 3$ split plot arrangement of treatments, fitted in a randomized complete block design (RCBD), replicated four times. The intercropping (sole egusi melon, sole okra and egusi melon-okra mixture) constituted the main plots, while the population densities of okra $(33,000,40,000$ and 50,000 plants $\mathrm{ha}^{-1}$ equivalent) into egusi melon were allocated to the subplots. Results of study showed that to maximize intercrop yield of okra in an egusi melon-okra intercrop, the optimal population density of okra is 33,000 plants ha ${ }^{-1}$, while that of 40,000 plants $^{-1} \mathrm{~h}^{-1}$ is optimal to maximize intercrop yield of egusi melon. Intercropping egusi melon and okra significantly $(\mathrm{P} \leq 0.05)$ reduced yields of egusi melon (37.5\% and $40.5 \%$ respectively, in years 2012 and 2013) and that of okra $(9.7 \%$ and 16.9 $\%$ respectively, in years 2012 and 2013). The highest mean land equivalent ratio value of 1.57 and highest land equivalent coefficient values of 0.60 and 0.63 respectively, in years 2012 and 2013, were recorded for okra sown into egusi melon at the population density of 40,000 plants ha ${ }^{-1}$. It is most advantageous having both crops in intercrop when okra is sown into egusi melon at the population density of 40,000 plants $\mathrm{ha}^{-1}$. This should therefore be recommended for Makurdi location, Nigeria.
\end{abstract}

\section{INTRODUCTION}

Okra (Abelmoschus esculentus L. Moench) belongs to the family Malvaceae and is one of the important vegetable crop grown in tropical and subtropical parts of the world (Christo and Onuh, 2005). World production of okra as fruit vegetable is estimated at 6 million tonnes per year, but in West Africa, it is estimated at 500,000 to 600,000 tonnes per year (Burkil, 1997). In Nigeria, okra ranked third in relation to consumption and production area, following tomato and pepper (Ibeawuchi, 2007). The crop is rich in both minerals and proteins which are both vital to man's growth and development and used by different people in different ways (Katung and Kashina, 2005). The immature pods are consumed as boiled vegetable and are also dried and used as soup thickeners or in stews (Yadev and Dhanker., 2002). Foliage of okra plants are known to provide good sources of fodder for livestoch (BOSADP, 1998). The mucilage preparation from the immature pod is used medicinally in the treatment of ulcers and in the reliefs of hemorrhoids (Yadev and Dhanker, 2002).

Egusi melon (Citrullus lunatus, Thunb) is a member of the family Curcurbitaceae (Badifu and Ogunsa, 1991). It is native of West Africa, where it was distributed and grown throughout the Mediterranean (Tindal, 1986). The world production of melon seeds in year 2002 was reported at 576,000 tonnes from 608,000 hectares (Brisibe et al., 2011). There has been a tremendous increase in the production of egusi melon, especially in Nigeria where it is cultivated over an area of 361,000 hectares with seed yield of about 347,000 tonnes per annum, probably because of the increased awareness of its economic value (Badifu and Ogunsa, 1991). The crop is popular in the country for its edible seed which contains approximately $40 \%$ oil, $28 \%$ protein and some important minerals 
(Ogbonna and Obi, 2010). The highly prized vegetable oil extracted from the seed is of high nutritional value, composed mainly of unsaturated fatty acids, which gives a unique flavor to foods during cooking (Ogbonna and Obi, 2010).

A number of studies have been conducted on monocropped egusi melon and okra as affected by population density (Okaka and Remison, 1999; Ijoyah et al., 2010), however, these studies did not reveal the optimal planting density of okra, particularly in an egusi melon-okra intercrop. In addition, there is a dearth of scientific information on the performance of egusi melon and okra under intercropping. An investigation was therefore undertaken with the objective of identifying the optimal plant density of okra that will maximize yields of egusi melon-okra intercrop as well as the yield response of component crops to intercropping.

\section{MATERIALS AND METHODS}

\subsection{Study location and crop varieties}

A field experiment was conducted from August to November, during the 2012 and 2013 cropping seasons at the Research Farm, University of Agriculture, Makurdi, Nigeria, to identify the optimum plant density of okra and intercropping effects on yields of egusi melon-okra mixture.

The okra variety 'NH47-4' was obtained from the National Institute for Horticultural Research and Training (NIHORT), Ibadan, Nigeria, while the egusi melon 'Itchier Udam' is a local variety, popularly grown by farmers in the locality. The varieties of both crops show good adaptation to Makurdi environment.

\subsection{Experimental design and crop arrangement}

The experiment was a $3 \times 3$ split plot arrangement of treatments, fitted in a randomized complete block design, and replicated four times. The intercropping, which consisted of sole egusi melon, sole okra and egusi melon-okra intercrop were allocated to the main plots, while the population densities of okra $\left(33,000,40,000\right.$ and 50,000 plants $\mathrm{ha}^{-1}$ equivalent) into egusi melon were assigned to the subplots. The experimental area cultivated was $418.5 \mathrm{~m}^{2}$ and consisted of 36 subplots. Each subplot had an area of $9.0 \mathrm{~m}^{2}$. The experimental field was cleared, ploughed and harrowed. Each plot consisted of 4 ridges. In sole egusi melon plot, each ridge consisted of 8 egusi melon stands, at an intra-row spacing of $35 \mathrm{~cm}$ (Okaka and Remison, 1999). A total of 32 egusi melon stands were sown in each plot. In sole okra plot,10 okra stands were planted on each ridge, at an intra-row spacing of $30 \mathrm{~cm}$ (Ijoyah et al., 2010), giving a total of 40 okra stands per plot. In the sole plots, egusi melon and okra were planted in a single row, on top of the ridge, at their recommended population density, while in the intercrop plots, egusi melon was sown in a single row on top of ridge, while okra was sown by the side of the ridge, and at the varied population densities of 33,000, 40,000 and 50,000 plants ha ${ }^{-1}$ equivalent. Two egusi melon and two okra seeds were sown at a depth of $2-3 \mathrm{~cm}$ and later thinned to one plant per stand at two weeks after planting (WAP).

\subsection{Cultural practices}

Weeding was done as the need arose. The recommended rate for mixed fertilizer NPK (15:15:15) for sole okra at the rate of $100 \mathrm{~kg} \mathrm{ha}^{-1}$ as described by Ekpete (2000), for sole egusi melon: mixed fertilizer NPK $(15: 15: 15)$ at the rate of $120 \mathrm{~kg} \mathrm{ha}^{-1}$, and for egusi melon-okra intercrop: mixed fertilizer at the rate of $120 \mathrm{~kg} \mathrm{ha}^{-1}$ (Enwezor et al., 1989). The fertilizer was applied twice to each treatment, at 4 and 8 WAP. Harvesting of okra was done when the tip of pod was observed to break easily when pressed with the finger tip (Usman, 2001). Egusi melon was harvested at 16 WAP, when the leaves turned yellowish and fallen off with stem drying, which were signs of senescence and crop maturity (Ijoyah et al., 2012).

\subsection{Data collected and statistical analysis}

Data collected on okra included days to attain $50 \%$ flowering (taken by counting the number of days from when crop was sown to when $50 \%$ flowered), plant height (measured in $\mathrm{cm}$ as the 
distance from the soil surface to the tip of the top most leaf), leaf area (measured in $\mathrm{cm}^{2}$ as described by Breda, (2003), using the length-width method: LXW, where L is the leaf length and W is the largest width of the leaf). The number of leaves, number of branches and number of pods per plant were obtained from a sample of 4 plants in each plot and averaged. The pod length and pod diameter were also measured in $\mathrm{cm}$. Fresh okra was harvested and weighed for pod weight in grams and total pods for each net plot area were also harvested and weighed for total yield $(\mathrm{kg})$ converted to $\mathrm{tha}^{-1}$.

Data collected for egusi melon included days to attain $50 \%$ flowering, number of branches per plant, number of leaves per plant, leaf area, number of fruits per plant, number of seeds per fruit, seed weight ( $\mathrm{g}$ ) and yield $\left(\mathrm{t} \mathrm{ha}^{-1}\right)$. Analysis of variance (ANOVA) for split plot design was carried out on each observation and the Least significant difference (LSD) was used for means separation $(\mathrm{P} \leq 0.05)$ following the procedure of Steel and Torrie (1980). Direct treatment effects and the magnitude of interactions were also determined.

\subsection{Evaluation of intercropping advantages}

The land equivalent ratio (LER) was determined as described by Willey (1985) using the formula:

$$
L E R=\frac{\text { Intercrop yield of crop } A}{\text { Sole crop yield of } A}+\frac{\text { Intercrop yield of crop } B}{\text { Sole crop yield of } B}
$$

The competitive ratio (CR) as described by Willey and Rao (1980) was determined using the formula:

$C R=L m / L o$, where; $L m$ : Partial LER for egusi melon; $L o:$ Partial LER for okra.

The percentage (\%) land saved as described by Willey (1985) using the formula:

$\%$ land saved $=100-1 /$ LER X 100

Aggressivity(A) gives a simple measure of how much the relative yield increase in component ' $a$ ' is greater than that for component ' $b$ ' as described by McGilchrist (1971) using the formula:

$$
A=\frac{\text { Mixture yield of }{ }^{\prime} a^{\prime}}{\text { Expected yield of }{ }^{\prime} a^{\prime}}-\frac{\text { Mixture yield of }{ }^{\prime} b^{\prime}}{\text { Expected yield of }{ }^{\prime} b^{\prime}}
$$

Where:

$\mathrm{A}=0$ : indicates that both crops are equally competitive; $\mathrm{A}=-$ : indicates dominated component

$\mathrm{A}=+$ : indicates dominant component

The land equivalent coefficient (LEC) as described by Adetiloye et al., (1983) was determined using the formula:

$L E C=L a \times L b$; where $L a: L E R$ of main crop; $L b: L E R$ of intercrop.

These calculations were used to assess the advantages of the intercropping system.

\section{RESULTS AND DISCUSSION}

\subsection{Growth and yield components of okra as affected by the effects of population density of okra and intercropping.}

The main effect of population densities of okra and intercropping did not significantly $(\mathrm{P} \leq 0.05)$ affect days to attain $50 \%$ flowering for okra (Table 1). Okra plant height significantly $(\mathrm{P} \leq 0.05)$ reduced as population density of okra increased from 40,000 to 50,000 plants per hectare. This could be linked to greater competition for available nutrients at higher plant densities. The result agreed with Majnoun et al., (2001) who reported that plant height of soybean decreased with an increase in plant population density up to $1,034,000$ plants per ha ${ }^{-1}$. Intercropping egusi melon and okra significantly $(\mathrm{P} \leq 0.05)$ reduced okra plant height in both years (Table 1$)$. The reduction in okra height under intercropping could have been induced by the intense overcrowding effect of the intercrops compared to sole cropping for available nutrients. This view agreed with that of Madu and Nwosu (2001), who reported that yam planted soles, generally have greater efficiency in utilizing growth environment. 
Number of branches per plant and number of okra leaves per plant decreased as population density of okra increased. Intercropping egusi melon and okra significantly $(\mathrm{P} \leq 0.05)$ reduced number of branches and number of okra leaves per plant (Table 1). This result agreed with Silwana and Lucas (2002) who reported that intercropping reduced vegetative growth of component crops.

Increasing population density of okra from 40,000 to 50,000 plants per ha ${ }^{-1}$ significantly $(\mathrm{P} \leq 0.05)$ reduced leaf area, number of pods per plant and pod length (Table 2). The lowest competition for growth resources which might have occurred at the reduced okra population density of 33,000 plants ha ${ }^{-1}$ could be attributed to the largest leaf area obtained. Ayoola and Makinde (2008) also reported that leaf area was wider with decrease in cassava population. Ijoyah et al., (2012) reported a reduction in leaf length and leaf width of intercropped egusi melon as compared to those obtained from egusi melon planted as sole crop.

Although, pod width was not significantly $(\mathrm{P} \leq 0.05)$ affected by the varied population density of okra, however, increasing okra population density to 50,000 plants ha ${ }^{-1}$ significantly $(\mathrm{P} \leq 0.05)$ reduced pod weight and yield (Table 2). The decline in yield could be linked to greater inter-plant competition, induced at higher density. Duthie et al., (1999) reported that yield per unit area tends to increase with plant up to a certain threshold and due to interplant competition, tends to decline. Sowing okra at the population density of 33,000 plants per ha ${ }^{-1}$ significantly $(\mathrm{P} \leq 0.05)$ increased okra yield by $13.2 \%$ and $17.9 \%$ respectively, in years 2012 and 2013, as compared to sowing okra at the population density of 40,000 plants $\mathrm{ha}^{-1}$, and by $21.0 \%$ and $23.1 \%$ respectively, in years 2012 and 2013, as compared to sowing okra at the population density of 50,000 plants per ha ${ }^{-1}$. Intercropping egusi melon and okra significantly $(\mathrm{P} \leq 0.05)$ reduced pod yield by $9.7 \%$ and $16.9 \%$ respectively, in years 2012 and 2013, as compared to that obtained from okra sown as a sole crop. This result agreed with those of Olufajo (1992) and Muoneke et al., (2007) who reported higher yield in sole cropping over intercropping.

Although, introducing okra into egusi melon at the varied population densities did not significantly $(\mathrm{P} \leq 0.05)$ affect days to attain $50 \%$ flowering for okra, however, height of intercropped okra, number of branches per okra plant and number of okra leaves per plant significantly $(\mathrm{P} \leq 0.05)$ reduced as population density of okra in the egusi melon-okra intercrop increased up to 50,000 plants $\mathrm{ha}^{-1}$ (Table 3).

Okra sown into egusi melon at the density of 33,000 plants ha ${ }^{-1}$ produced the largest leaf area, highest number of pods, highest pod weight and highest pod yields of $6.5 \mathrm{t}$ ha- 1 and $6.3 \mathrm{tha}^{-1}$ respectively, in years 2012 and 2013 (Table 4).

\subsection{Growth and yield components of egusi melon as affected by the effects of population density of okra and intercropping.}

Though days to attain $50 \%$ flowering for egusi melon was not significantly $(\mathrm{P} \leq 0.05)$ affected by the varied population density of okra, however, intercropping egusi melon and okra significantly $(\mathrm{P} \leq 0.05)$ reduced days to attain $50 \%$ flowering for egusi melon (Table 5). The longer days taken to attain $50 \%$ flowering for sole egusi melon compared to intercropped egusi melon contradicted the results of Ijoyah et al., (2012), who reported longer days to attain $50 \%$ flowering for intercropped egusi melon in an egusi melon-maize intercrop. The difference in results could be due to the growth habit of component crops, and possibly the arrangement of the component crops in the intercrop.

Increasing the population density of okra from 33,000 plants ha ${ }^{-1}$ to 40,000 plants $^{-1}$ increased number of branches of egusi melon, number of leaves per plant and leaf area of egusi melon, but further increase in population density of okra from 40,000 plants ha ${ }^{-1}$ to 50,000 plants $^{-1}$ significantly $(\mathrm{P} \leq 0.05)$ reduced the parameters (Table 5). The greater competition for growth resources at higher densities of okra could have been responsible for the reduction in number of branches of egusi melon, number of leaves per plant and leaf area of egusi melon. Intercropping egusi melon and okra significantly $(\mathrm{P} \leq 0.05)$ reduced number of branches of egusi melon, number of leaves per plant and leaf area of egusi melon (Table 5). The decrease in number of branches of egusi melon, number of leaves per plant and leaf area of egusi melon when intercropped with okra, could be attributed to the shading effect by the okra plant, thereby limiting the photosynthetic absorption for light by the intercropped egusi melon, thus resulting in the reduction in number of 
branches, number of leaves and leaf area. Similar results were also recorded for the main effects of population density and intercropping on number of egusi melon fruits per plant, number of egusi melon seeds per fruit, weight of seeds per fruit and yield of egusi melon (Table 6). Planting okra at the population density of 40,000 plants $\mathrm{ha}^{-1}$ significantly $(\mathrm{P} \leq 0.05)$ increased yield of egusi melon by $25.0 \%$ and $13.5 \%$ respectively, in years 2012 and 2013, compared to that produced when okra was sown at the population density of 33,000 plants per ha ${ }^{-1}$ and by $37.5 \%$ and $40.5 \%$ respectively, in years 2012 and 2013 as compared to when okra was sown at the population density of 50,000 plants $\mathrm{ha}^{-1}$. Intercropping egusi melon and okra significantly $(\mathrm{P} \leq 0.05)$ reduced yield of egusi melon by $40.5 \%$ and $48.7 \%$ respectively, in years 2012 and 2013, as compared to that obtained from sole egusi melon (Table 6).

The highest number of branches, number of leaves, largest leaf area (Table 7), highest number of fruits, number of seeds per fruit, weight of seeds per fruit and highest yield of intercropped egusi melon were obtained when okra was sown in the intercrop at the population density of 40,000 plants $\mathrm{ha}^{-1}$ (Table 8).

\subsection{Evaluation of intercropping advantages.}

Irrespective of the main effects of population density of okra and intercropping, total intercrop yields were greater than the intercrop yields of component crops (Table 9). The land equivalent ratio (LER) values for all treatments at the 2-way interaction of intercropping $\mathrm{x}$ population density of okra were all above 1.0, indicating yield advantage of the intercropping system (Table 10). Average of both years showed that the highest LER of 1.57 was recorded when okra was sown into egusi melon at the population density of 40,000 plants $^{-1} \mathrm{~h}^{-1}$, signifying that it is most advantageous having both crops in intercropping at this interaction level. This could be due to the highest efficiency of resource utilization attained at the treatment level. The level of treatment also recorded an average of $34.5 \%$ of land saved, which could be used for other agricultural purposes. The highest land equivalent coefficient (LEC) values of 0.60 and 0.63 were respectively recorded in years 2012 and 2013 from okra sown into egusi melon at the population density of 40,000 plants ha ${ }^{-}$ ${ }^{1}$ (Table 10). Adetiloye et al., (1983) reported that for a two crop mixture, the minimum expected productivity coefficient is $25 \%$. While the lowest competitive ratio (CR) was recorded for okra sown into egusi melon at the population density of 33,000 plants $\mathrm{ha}^{-1}$, the highest aggressivity was obtained sowing okra into egusi melon at the population density of 40,000 plants $\mathrm{ha}^{-1}$, the level at which both crops dominated each other (Table 10).

\section{CONCLUSION}

From the results obtained, it can be concluded that sowing okra into egusi melon at the population density of 33,000 plants $\mathrm{ha}^{-1}$ gave the highest intercrop yield of okra, while the highest intercrop yield of egusi melon was obtained sowing okra into egusi melon at the population density of 40,000 plants ha ${ }^{-1}$, in addition to recording the highest land equivalent ratio (LER) and highest land equivalent coefficient (LEC) values. 
Table 1. Main effects of population density of okra and intercropping on days to attain 50\% flowering for okra, okra plant height, number of branches per plant and number of okra leaves per plant in years 2012 and 2013 at Makurdi, Nigeria

\begin{tabular}{|c|c|c|c|c|c|c|c|c|}
\hline & \multicolumn{2}{|c|}{$\begin{array}{l}\text { Days to attain } 50 \% \\
\text { flowering }\end{array}$} & \multicolumn{2}{|c|}{$\begin{array}{l}\text { Okra plant height } \\
(\mathrm{cm})\end{array}$} & \multicolumn{2}{|c|}{$\begin{array}{c}\text { Number of } \\
\text { branches per plant }\end{array}$} & \multicolumn{2}{|c|}{$\begin{array}{c}\text { Number of okra leaves } \\
\text { per plant }\end{array}$} \\
\hline & 2012 & 2013 & 2012 & 2013 & 2012 & 2013 & 2012 & 2013 \\
\hline \multicolumn{9}{|c|}{$\begin{array}{l}\text { Population density of } \\
\text { okra }\end{array}$} \\
\hline 33,000 & 67.4 & 67.8 & 86.0 & 90.4 & 5.9 & 5.9 & 21.4 & 25.3 \\
\hline 40,000 & 66.9 & 66.5 & 84.0 & 86.2 & 4.8 & 4.9 & 19.8 & 20.5 \\
\hline 50,000 & 66.8 & 66.4 & 74.2 & 76.0 & 4.3 & 4.4 & 18.4 & 17.2 \\
\hline $\operatorname{LSD}(\mathrm{P} \leq 0.05)$ & 2.5 & 5.2 & 1.2 & 3.4 & 0.3 & 0.4 & 8.5 & 10.8 \\
\hline \multicolumn{9}{|l|}{ Intercropping } \\
\hline Sole okra & 66.7 & 68.8 & 90.8 & 95.6 & 4.7 & 5.3 & 21.2 & 25.4 \\
\hline Egusi melon-okra & 66.4 & 65.5 & 72.2 & 80.0 & 4.3 & 3.5 & 18.5 & 20.5 \\
\hline LSD $(\mathrm{P} \leq 0.05)$ & 4.5 & 7.5 & 16.4 & 12.2 & 0.2 & 1.2 & 2.0 & 3.1 \\
\hline
\end{tabular}

Table 2. Main effects of population density of okra and intercropping on leaf area of okra, number of pods per plant, pod length, pod width, pod weight and okra yield.

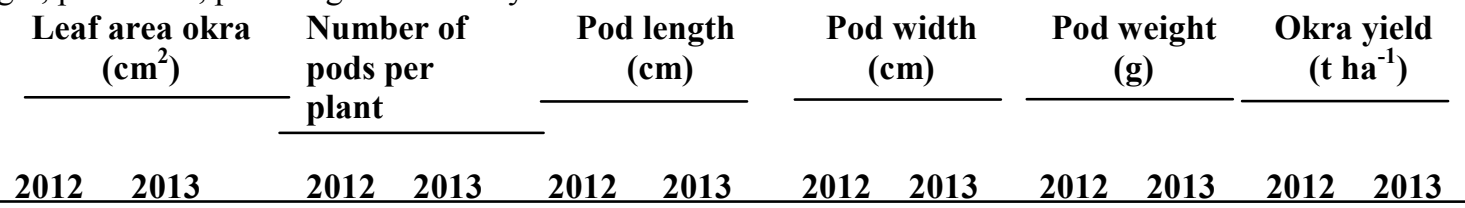

\begin{tabular}{|c|c|c|c|c|c|c|c|c|c|c|c|c|}
\hline \multicolumn{13}{|l|}{$\begin{array}{l}\text { Population } \\
\text { density } \\
\text { of okra }\end{array}$} \\
\hline 33,000 & 376.1 & 391.7 & 14.0 & 15.3 & 8.8 & 9.7 & 9.1 & 9.2 & 27.6 & 30.2 & 7.6 & 7.8 \\
\hline 40,000 & 364.5 & 368.3 & 12.7 & 12.0 & 8.1 & 8.0 & 9.0 & 8.7 & 24.3 & 26.0 & 6.6 & 6.4 \\
\hline 50,000 & 302.4 & 294.8 & 10.9 & 9.2 & 7.3 & 7.6 & 9.0 & 8.4 & 22.0 & 23.0 & 6.0 & 6.0 \\
\hline $\operatorname{LSD}(\mathrm{P} \leq 0.05)$ & 8.7 & 10.3 & 1.2 & 2.2 & 0.6 & 0.8 & 5.5 & 6.2 & 1.5 & 2.4 & 0.4 & 0.2 \\
\hline \multicolumn{13}{|l|}{ Intercropping } \\
\hline Sole okra & 410.4 & 460.6 & 13.5 & 14.2 & 8.9 & 8.6 & 9.7 & 10.5 & 28.4 & 30.7 & 6.2 & 6.5 \\
\hline $\begin{array}{l}\text { Egusi melon - } \\
\text { okra }\end{array}$ & 316.4 & 309.4 & 11.3 & 11.0 & 7.3 & 6.4 & 8.9 & 8.4 & 23.1 & 24.2 & 5.6 & 5.4 \\
\hline $\operatorname{LSD}(\mathrm{P} \leq 0.05)$ & 11.2 & 12.2 & 1.7 & 1.4 & 0.6 & 1.2 & 0.4 & 0.6 & 0.4 & 3.5 & 0.4 & 0.5 \\
\hline
\end{tabular}

Table 3. Interaction of intercropping $x$ population density of okra on days to attain $50 \%$ flowering for okra, okra plant height, number of branches per plant and number of okra leaves per plant in years 2012 and 2013 at Makurdi, Nigeria

\begin{tabular}{|c|c|c|c|c|c|c|c|c|c|}
\hline \multirow[t]{2}{*}{ Intercropping } & \multirow[t]{2}{*}{$\begin{array}{c}\text { Population } \\
\text { density of } \\
\text { okra }\end{array}$} & \multicolumn{2}{|c|}{$\begin{array}{c}\text { Days to } \\
\text { attain } 50 \% \\
\text { flowering } \\
\end{array}$} & \multicolumn{2}{|c|}{$\begin{array}{c}\text { Okra } \\
\text { plant } \\
\text { height }(\mathbf{c m})\end{array}$} & \multicolumn{2}{|c|}{$\begin{array}{c}\text { Number of } \\
\text { branches } \\
\text { per plant }\end{array}$} & \multicolumn{2}{|c|}{$\begin{array}{c}\text { Number of } \\
\text { okra leaves } \\
\text { per plant }\end{array}$} \\
\hline & & 2012 & 2013 & 2012 & 2013 & 2012 & 2013 & 2012 & 2013 \\
\hline \multirow{3}{*}{ Sole okra } & 33,000 & 68.0 & 68.5 & 94.6 & 95.8 & 4.9 & 5.2 & 22.7 & 23.4 \\
\hline & 40,000 & 67.8 & 67.2 & 92.6 & 92.3 & 4.6 & 4.2 & 20.5 & 20.2 \\
\hline & 50,000 & 67.3 & 67.5 & 85.1 & 84.6 & 4.5 & 4.0 & 20.3 & 18.0 \\
\hline \multirow{4}{*}{$\begin{array}{l}\text { Egusi melon- } \\
\text { Okra }\end{array}$} & 33,000 & 66.9 & 67.2 & 80.7 & 81.4 & 5.9 & 5.7 & 20.0 & 22.3 \\
\hline & 40,000 & 66.0 & 66.4 & 77.4 & 78.2 & 4.8 & 4.6 & 19.1 & 19.3 \\
\hline & 50,000 & 66.3 & 66.6 & 63.2 & 64.0 & 4.1 & 4.2 & 16.6 & 17.0 \\
\hline & LSD $(\mathrm{P} \leq 0.05)$ & 3.1 & 4.2 & 2.0 & 2.5 & 0.3 & 0.2 & 0.4 & 0.6 \\
\hline
\end{tabular}


Table 4. Interaction of intercropping x population density of okra on leaf area of okra, number of pods per plant, pod length, pod width, pod weight and okra yield in years 2012 and 2013 at Makurdi, Nigeria

\begin{tabular}{|c|c|c|c|c|c|c|c|c|c|c|c|c|c|}
\hline \multirow[b]{2}{*}{ Intercropping } & \multirow[b]{2}{*}{$\begin{array}{l}\text { Population } \\
\text { density of } \\
\text { okra }\end{array}$} & \multicolumn{2}{|c|}{$\begin{array}{c}\text { Leaf area of okra } \\
\left(\mathrm{cm}^{2}\right)\end{array}$} & \multicolumn{2}{|c|}{$\begin{array}{c}\text { Number } \\
\text { pods per } \\
\text { plant }\end{array}$} & \multicolumn{2}{|c|}{$\begin{array}{l}\text { Pod length } \\
\text { (cm) }\end{array}$} & \multicolumn{2}{|c|}{$\begin{array}{l}\text { Pod width } \\
\text { (cm) }\end{array}$} & \multicolumn{2}{|c|}{$\begin{array}{c}\text { Pod weight } \\
(\mathrm{g})\end{array}$} & \multicolumn{2}{|c|}{$\begin{array}{c}\text { Okra yield } \\
\left(\mathrm{t} \mathrm{ha}^{-1}\right)\end{array}$} \\
\hline & & 2012 & 2013 & $\frac{p}{2012}$ & $\frac{n t}{2013}$ & 2012 & 2013 & 2012 & 2013 & 2012 & 2013 & 2012 & 2013 \\
\hline & 33,000 & 424.4 & 497.3 & 15.1 & 15.8 & 8.5 & 9.2 & 9.4 & 9.6 & 29.4 & 30.2 & 6.7 & 6.7 \\
\hline \multirow[t]{2}{*}{ Sole okra } & 40,000 & 366.6 & 353.3 & 12.4 & 12.0 & 7.8 & 7.6 & 8.2 & 8.4 & 28.6 & 28.1 & 5.6 & 5.4 \\
\hline & 50,000 & 327.5 & 306.0 & 10.9 & 9.3 & 6.0 & 7.5 & 8.0 & 8.2 & 27.2 & 27.0 & 4.3 & 4.0 \\
\hline \multirow{3}{*}{$\begin{array}{l}\text { Egusi melon - } \\
\text { okra }\end{array}$} & 33,000 & 341.6 & 390.0 & 12.9 & 13.2 & 8.9 & 8.7 & 9.1 & 9.2 & 28.1 & 29.4 & 6.5 & 6.3 \\
\hline & 40,000 & 314.9 & 315.0 & 11.3 & 11.2 & 6.4 & 6.0 & 8.0 & 8.0 & 26.7 & 27.0 & 5.3 & 5.0 \\
\hline & 50,000 & 270.3 & 258.0 & 9.6 & 8.0 & 6.6 & 5.4 & 7.7 & 7.3 & 26.4 & 24.0 & 4.0 & 4.0 \\
\hline LSD & $(\mathrm{P} \leq 0.05)$ & 11.3 & 12.2 & 0.7 & 0.5 & 0.8 & 0.6 & 0.6 & 0.8 & 0.5 & 0.8 & 1.1 & 1.3 \\
\hline
\end{tabular}

Table 5. Main effects of population density of okra and intercropping on days to attain $50 \%$ flowering for egusi melon, number of branches per plant, number of leaves per plant and leaf area of egusi melon in yeas 2012 and 2013 at Makurdi, Nigeria

\begin{tabular}{|c|c|c|c|c|c|c|c|c|}
\hline & \multicolumn{2}{|c|}{$\begin{array}{c}\text { Days to } \\
\text { attain } 50 \% \\
\text { flowering for egusi melon }\end{array}$} & \multicolumn{2}{|c|}{$\begin{array}{l}\text { Number } \\
\text { of } \\
\text { branches } \\
\text { per plant }\end{array}$} & \multicolumn{2}{|c|}{$\begin{array}{c}\text { Number } \\
\text { of } \\
\text { leaves } \\
\text { per plant }\end{array}$} & \multicolumn{2}{|c|}{$\begin{array}{l}\text { Leaf area of } \\
\text { egusi melon } \\
\left(\mathrm{cm}^{2}\right)\end{array}$} \\
\hline $\begin{array}{c}\text { Population } \\
\text { density } \\
\text { of } \\
\text { okra }\end{array}$ & 2012 & 2013 & 2012 & 2013 & 2012 & 2013 & 2012 & 2013 \\
\hline $\begin{array}{c}33,000 \\
40,000 \\
50,000 \\
\mathrm{LSD}(\mathrm{P} \leq 0.05)\end{array}$ & $\begin{array}{c}43.6 \\
43.6 \\
43.8 \\
0.8\end{array}$ & $\begin{array}{c}43.2 \\
43.4 \\
42.8 \\
1.0\end{array}$ & $\begin{array}{l}7.2 \\
7.8 \\
7.4 \\
0.2\end{array}$ & $\begin{array}{l}7.8 \\
8.9 \\
7.2 \\
0.5\end{array}$ & $\begin{array}{c}113.8 \\
136.7 \\
133.8 \\
6.0\end{array}$ & $\begin{array}{c}118.3 \\
138.5 \\
135.2 \\
8.2\end{array}$ & $\begin{array}{c}123.8 \\
132.3 \\
127.0 \\
7.8\end{array}$ & $\begin{array}{c}127.7 \\
152.4 \\
134.2 \\
14.7\end{array}$ \\
\hline $\begin{array}{l}\text { Intercropping } \\
\text { Sole egusi melon } \\
\text { Egusi melon- okra } \\
\text { LSD }(\mathrm{P} \leq 0.05)\end{array}$ & $\begin{array}{c}44.4 \\
42.9 \\
0.4\end{array}$ & $\begin{array}{c}43.9 \\
42.2 \\
0.2\end{array}$ & $\begin{array}{l}8.5 \\
7.1 \\
1.0\end{array}$ & $\begin{array}{l}9.6 \\
6.2 \\
1.6\end{array}$ & $\begin{array}{c}134.4 \\
118.4 \\
11.8\end{array}$ & $\begin{array}{c}138.8 \\
120.2 \\
9.0\end{array}$ & $\begin{array}{c}145.0 \\
123.0 \\
7.0\end{array}$ & $\begin{array}{c}163.3 \\
102.9 \\
9.0\end{array}$ \\
\hline
\end{tabular}

Table 6. Main effects of population density of okra and intercropping on number of egusi melon fruits per plant, number of egusi melon seeds per fruit, weight of seeds per fruit and yield of egusi melon in years 2012 and 2013, at Makurdi, Nigeria

\begin{tabular}{|c|c|c|c|c|c|c|c|c|}
\hline \multirow[b]{2}{*}{$\begin{array}{c}\text { Population } \\
\text { density of } \\
\text { okra }\end{array}$} & \multicolumn{2}{|c|}{$\begin{array}{c}\text { Number of egusi } \\
\text { melon fruits per plant }\end{array}$} & \multicolumn{2}{|c|}{$\begin{array}{c}\text { Number of egusi } \\
\text { melon seeds per fruit }\end{array}$} & \multicolumn{2}{|c|}{$\begin{array}{c}\text { Weight of seeds } \\
\text { per fruit }(\mathrm{g})\end{array}$} & \multicolumn{2}{|c|}{$\begin{array}{l}\text { Yield of egusi melon } \\
\left(\mathrm{t} \mathrm{ha}^{-1}\right)\end{array}$} \\
\hline & 2012 & 2013 & 2012 & 2013 & 2012 & 2013 & 2012 & 2013 \\
\hline $\begin{array}{c}33,000 \\
40,000 \\
50,000 \\
\text { LSD }(\mathrm{P} \leq 0.05)\end{array}$ & $\begin{array}{l}5.3 \\
5.4 \\
4.7 \\
0.4\end{array}$ & $\begin{array}{l}5.4 \\
5.8 \\
4.4 \\
0.2\end{array}$ & $\begin{array}{c}122.4 \\
130.9 \\
98.3 \\
4.5\end{array}$ & $\begin{array}{c}130.6 \\
138.0 \\
100.1 \\
6.2\end{array}$ & $\begin{array}{c}49.4 \\
54.9 \\
41.0 \\
3.5\end{array}$ & $\begin{array}{c}47.2 \\
58.6 \\
40.0 \\
5.2\end{array}$ & $\begin{array}{l}3.0 \\
4.0 \\
2.5 \\
0.6\end{array}$ & $\begin{array}{l}3.2 \\
3.7 \\
2.2 \\
0.3\end{array}$ \\
\hline $\begin{array}{l}\text { Intercropping } \\
\text { Sole egusi melon } \\
\text { Egusi melon-okra }\end{array}$ & $\begin{array}{l}6.2 \\
4.1\end{array}$ & $\begin{array}{l}7.6 \\
4.5\end{array}$ & $\begin{array}{l}142.6 \\
85.1\end{array}$ & $\begin{array}{c}150.3 \\
90.6\end{array}$ & $\begin{array}{l}61.0 \\
35.9\end{array}$ & $\begin{array}{l}58.4 \\
38.2\end{array}$ & $\begin{array}{l}3.7 \\
2.2\end{array}$ & $\begin{array}{l}3.9 \\
2.0\end{array}$ \\
\hline $\operatorname{LSD}(\mathrm{P} \leq 0.05)$ & 1.3 & 1.8 & 8.4 & 10.6 & 12.5 & 7.4 & 1.2 & 0.5 \\
\hline
\end{tabular}


Table 7. Interaction of intercropping x population density of okra on days to attain $50 \%$ flowering for egusi melon, number of branches of egusi melon, number leaves per plant and leaf area of egusi melon in years 2012 and 2013, at Makurdi, Nigeria.

\begin{tabular}{|c|c|c|c|c|c|c|c|c|c|}
\hline \multirow[t]{4}{*}{ Intercropping } & \multirow{3}{*}{$\begin{array}{c}\text { Population } \\
\text { density } \\
\text { of } \\
\text { okra }\end{array}$} & \multirow{2}{*}{\multicolumn{2}{|c|}{$\begin{array}{c}\text { Days to } \\
\text { attain } 50 \% \\
\text { flowering for egusi } \\
\text { melon } \\
\end{array}$}} & \multirow{2}{*}{\multicolumn{2}{|c|}{$\begin{array}{c}\text { Number } \\
\text { of branches } \\
\text { of egusi melon }\end{array}$}} & \multicolumn{2}{|c|}{$\begin{array}{c}\text { Number } \\
\text { of } \\
\text { leaves per plant }\end{array}$} & \multicolumn{2}{|c|}{$\begin{array}{c}\text { Leaf area } \\
\left(\mathrm{cm}^{2}\right)\end{array}$} \\
\hline & & & & & & & & & \\
\hline & & 2012 & 2013 & 2012 & 2013 & 2012 & 2013 & 2012 & 2013 \\
\hline & 33,000 & 42.9 & 43.4 & 6.8 & 6.5 & 99.8 & 100.2 & 117.6 & 116.4 \\
\hline \multirow{3}{*}{$\begin{array}{l}\text { Egusi melon- } \\
\text { okra }\end{array}$} & 40,000 & 42.8 & 42.5 & 7.7 & 8.0 & 131.9 & 135.2 & 128.5 & 146.0 \\
\hline & 50,000 & 43.1 & 42.8 & 6.9 & 6.5 & 123.6 & 127.0 & 123.0 & 117.9 \\
\hline & $\begin{array}{c}\text { LSD } \\
(\mathrm{P} \leq 0.05)\end{array}$ & 2.9 & 3.8 & 0.3 & 0.5 & 4.2 & 10.2 & 4.2 & 7.1 \\
\hline
\end{tabular}

Table 8. Interaction of intercropping x population density of okra on number of egusi melon fruits per plant, number of egusi melon seeds per fruit, weight of seeds per fruit and yield of egusi melon in years 2012 and 2013 , at Makurdi, Nigeria

\begin{tabular}{|c|c|c|c|c|c|c|c|c|c|}
\hline \multirow[b]{2}{*}{ Intercropping } & \multirow{2}{*}{$\begin{array}{l}\text { Population } \\
\text { density of } \\
\text { okra }\end{array}$} & \multicolumn{2}{|c|}{$\begin{array}{c}\text { Number of egusi } \\
\text { melon fruits per } \\
\text { plant }\end{array}$} & \multicolumn{2}{|c|}{$\begin{array}{l}\text { Number of egusi } \\
\text { melon seeds per } \\
\text { fruit }\end{array}$} & \multicolumn{2}{|c|}{$\begin{array}{c}\text { Weight of seeds per } \\
\text { fruit (g) }\end{array}$} & \multicolumn{2}{|c|}{$\begin{array}{l}\text { Yield of egusi } \\
\text { melon }\left(\mathrm{t} \mathrm{ha} \mathbf{~ h}^{-1}\right)\end{array}$} \\
\hline & & 2012 & 2013 & 2012 & 2013 & 2012 & 2013 & 2012 & 2013 \\
\hline & 33,000 & 4.2 & 5.0 & 60.5 & 71.3 & 39.7 & 42.7 & 2.0 & 2.2 \\
\hline $\begin{array}{l}\text { Egusi melon- } \\
\text { okra }\end{array}$ & 40,000 & 4.6 & 6.0 & 88.3 & 92.3 & 50.5 & 50.3 & 2.6 & 3.2 \\
\hline LSD & $\begin{array}{c}50,000 \\
(\mathrm{P} \leq 0.05)\end{array}$ & $\begin{array}{l}3.8 \\
0.3\end{array}$ & $\begin{array}{l}4.2 \\
0.6\end{array}$ & $\begin{array}{l}66.2 \\
10.0\end{array}$ & $\begin{array}{c}63.1 \\
8.3\end{array}$ & $\begin{array}{c}27.5 \\
7.7\end{array}$ & $\begin{array}{c}30.3 \\
6.5\end{array}$ & $\begin{array}{l}1.7 \\
0.4\end{array}$ & $\begin{array}{l}2.0 \\
0.6\end{array}$ \\
\hline
\end{tabular}

Table 9. Sole crop yields, intercrop yields and total intercrop yield as affected by the main effects of population density of okra and intercropping in an egusi melon -okra intercrop, in years 2012 and 2013, at Makurdi, Nigeria.

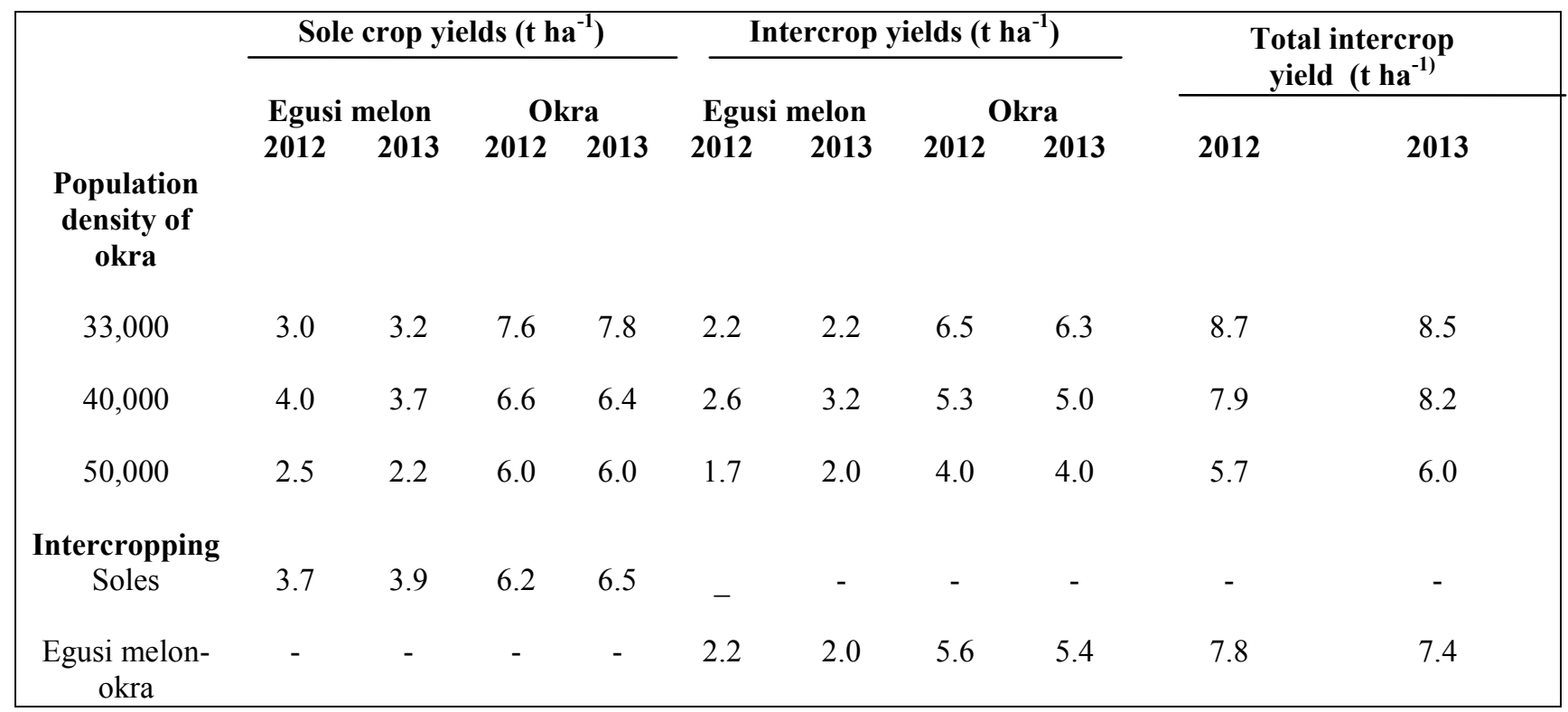


Table 10. Evaluation of yield advantages of egusi melon-okra intercrop as influenced by the interaction of population density of okra x intercropping in years 2012 and 2013, at Makurdi, Nigeria

\begin{tabular}{|c|c|c|c|c|c|c|c|c|c|c|c|c|c|c|c|}
\hline \multirow[t]{2}{*}{ Intercropping } & \multirow{2}{*}{$\begin{array}{c}\text { Population } \\
\text { density of } \\
\text { okra }\end{array}$} & \multicolumn{2}{|c|}{$\mathrm{Lm}$} & \multicolumn{2}{|c|}{ Lo } & \multicolumn{2}{|c|}{ LER } & \multicolumn{2}{|c|}{$\mathrm{CR}$} & \multicolumn{2}{|c|}{$\%$ land saved } & \multicolumn{2}{|c|}{ Aggressivity } & \multicolumn{2}{|c|}{ LEC } \\
\hline & & 2012 & 2013 & 2012 & 2013 & 2012 & 2013 & 2012 & 2013 & 2012 & 2013 & 2012 & 2013 & 2012 & 2013 \\
\hline \multirow{3}{*}{$\begin{array}{l}\text { Egusi melon- } \\
\text { okra }\end{array}$} & 33,000 & 0.54 & 0.56 & 1.05 & 0.97 & 1.59 & 1.53 & 0.51 & 0.58 & 37.0 & 35.0 & -0.51 & -0.41 & 0.57 & 0.54 \\
\hline & 40,000 & 0.70 & 0.82 & 0.85 & 0.77 & 1.55 & 1.59 & 0.82 & 1.06 & 35.0 & 37.0 & -0.15 & 0.05 & 0.60 & 0.63 \\
\hline & 50,000 & 0.46 & 0.51 & 0.65 & 0.62 & 1.12 & 1.13 & 0.71 & 0.82 & $11.0^{\circ}$ & 12.0 & -0.19 & -0.11 & 0.30 & 0.32 \\
\hline
\end{tabular}

LER: Land equivalent ratio

Aggressivity (A) where:

$\mathrm{A}=0$ (component crops are equally competitive)

$\mathrm{A}=-$ value (Dominated crop)

$\mathrm{A}=+$ value (Dominant crop) Lm: Partial LER for egusi melon CR: Competitive ratio Lo: Partial LER for okra

LEC: Land equivalent coefficient

\section{References}

[1] Adetiloye P.O., Ezedinma F.O.C., Okigbo B.N., Ecological Modeling 19 (1983) 27-39.

[2] Ayoola O.T., Makinde E.A., Tropical and Subtropical Agroecosystems 8 (3) (2008) 235-241.

[3] Badifu G.I.O., Ogunsa A.O., Plant Foods and Human Nutrition 41 (1991) 35-44.

[4] BOSADP (1998). Cropping recommendations. Borno State Agricultural Development Programme, Annual Report, Pp. 76.

[5] Breda N.J., Journal of Experimental Botany 54 (2003) 2403-2417.

[6] Brisibe E.A., Udensi O., Ntui V.O., Out P.A., Chukwurah P.N., African Journal of Plant Science 5(13) (2011) 759-766.

[7] Burkil H.M. (1997). The useful plants of tropical West Africa. $43^{\text {rd }}$ Ed., Royal botanical gardens, Kew, Pp. 166-179.

[8] Christo E.I., Onuh M.O. (2005). Influence of plant spacing on the growth and yield of okra (Abelmoschus esculentus (L) Moench). Proceedings of the $39^{\text {th }}$ conference of the Agricultural Society of Nigeria, Benin, 2005, pp. 51-53.

[9] Duthie J.A., Shrefler J.W., Roberts B.W., Edelson J.V., Crop Science Journal 39 (1999) 406412.

[10] Ekpete D.M., Nigerian Agricultural Journal 13 (2000) 96-102.

[11] Enwezor W.O.E., Udo J., Ajotade K.A. (1989). Fertilizer procurement and distribution, fertilizer use and management practice for crops in Nigeria. Savenda Publishers, Nsukka, Nigeria, pp. 25-28.

[12] Ibeawuchi I.K., Nature and Science 5(1) (2007) 46-49.

[13] Ijoyah M.O., Alexander A., Fanen F.T., Agriculture and Biology Journal of Northern America (6) (2012) 1328-1332.

[14] Ijoyah M.O., Atanu S.O., Ojo S., Journal of Applied Biosciences 32 (2010) 2015-2019.

[15] Katung M.D., Kachina B.D. (2005). Time of partial defoliation and GA3 effects on growth indices and yield of okra (Abelmoschus esculentus (L.) Moench). Proceeding of the $39^{\text {th }}$ conference of the Agricultural Society of Nigeria, Benin, 2005, pp. 210-213.

[16] Madu F.O., Nwosu S.K. (2001). Effect of fertilizer and time of interplanting maize on the performance of yam-maize intercrop. Proceedings of the $2^{\text {nd }}$ annual farming systems research and extension workshop in Southern Eastern Nigeria, Umudike, January 10-14, pp. 27-30. 
[17] Majnoun H.N., Ellis R.H., Yazdi-Samadi B., Journal of Science and Technology 3 (2001)131139.

[18] McGilchrist C.A., Biometrics 27 (1971) 659-671.

[19] Muoneke C.O., Ogwuche M.A.O., Kalu B.A., African Journal of Agricultural Research 2(12) (2007) 667-677.

[20] Ogbonna P.E., Obi I.U. (2010). Aspects of reproductive character of egusi melon. Proceedings of the $34^{\text {th }}$ annual conference of genetics society of Nigeria, 22-27.

[21] Okaka V.B., Remison S.U., Nigeria Agricultural Journal 30 (1999) 49-58.

[22] Olufajo O.O., Tropical Oil Seeds Journal 1 (1992) 27-33.

[23] Silwana T.T., Lucas E.O., Journal of Agricultural Science 138 (2002) 193-200.

[24] Steel G.O., Torrie J.H. (1980). Principles and procedures of statistics. A biometrical approach. $2^{\text {nd }}$ edition, McGraw-Hill Book International Company, New York, Pp. 633.

[25] Tindal H.D. (1986). Vegetables in the tropics. $1^{\text {st }}$ edition, Macmillan Publishers, Hong Kong, pp. 325-327.

[26] Usman S.D., Seed Research 29(1) (2001) 47-51.

[27]Willey R.W., Experimental Agriculture 21 (1985) 119-133.

[28] Willey R.W., Rao M.R., Experimental Agriculture 16 (1980) 117-125.

[29] Yadev S.K., Dhanker B.S., Vegetable Science 27 (2002) 70-74. 